\title{
Persons with Disabilities, A Lagging Group of Society in Uttarakhand: From Commitments to Outcomes
}

\author{
Manisha Shah*, J.C. Joshi, Jyoti Kundal \\ Department of History and Archaeology H.N.B. Garhwal University (A Central University) Srinagar, \\ Campus Tehri Garhwal Uttarakhand (India) \\ Department of History and Archaeology H.N.B. Garhwal University (A Central University) Srinagar, Campus \\ Tehri Garhwal Uttarakhand (India) \\ H.N.B. Garhwal University (A Central University) Srinagar, Campus Pauri Garhwal Uttarakhand (India)
}

\begin{abstract}
The term 'Persons with Disabilities' applies to all those people who have long-term physical, mental, intellectual or sensory impairments that, in the face of various negative attitudes or physical obstacles, may prevent disabled persons from participating fully in society. They are routinely subjected to all forms of discrimination, denial and deprivation of rights with the result that they are often marginalised and excluded. There have been deep and persistent negative stereotypes and prejudices against persons with certain conditions and differences. Despite having a sound legal framework and a plethora of programmes, schemes, rules and regulations corresponding improvement in the circumstances of PWDs are not visible. The rate of illiteracy, unemployment, health and poverty among them is alarming. It is widely recognized that the education, employment, skill trainings and income generation are key factors for empowering and promoting the inclusion of people with disabilities in society.
\end{abstract}

Keywords: Disabled, Impairment, Negligence, Social Barriers, Rehabilitation, Isolation

\section{INTRODUCTION}

Uttarakhand, a Himalayan state is one of the most beautiful and enchanting region of northern India. Nature has endowed this land a pure and pristine natural beauty, peace and spiritual bliss. The state is also referred as 'Dev Bhoomi' the Land of Gods. Uttarakhand was carved out from the hilly districts of Uttar Pradesh after mass agitations and given an independent status as the $10^{\text {th }}$ Himalayan state and the $27^{\text {th }}$ state of the Republic of India on $9^{\text {th }}$ November, 2000. Most of the northern parts of the state are part of Greater Himalayan ranges, covered by the high magnificent Himalayan peaks and glaciers. The total geographical area of the Uttarakhand is about 53,483 sq. km, constitutes about $1.69 \%$ of area of the country as a whole. The state is divided into two divisions, Garhwal and Kumaon with a total of thirteen (13) districts, seven in Garhwal and six in Kumaon region.

According to the Census 2001, the total population of Uttarakhand was 8,489,349 and out of this 194,769 persons are living with disability. Persons with Disabilities (PWDs) are some of the state's fringe and excluded groups and issues of which have been forgotten by the mainstream development. Table below portrayed the distribution of type of disability which disabled persons share in a state and country.

Number and Percentage of Type of Disabilities of PWDs (as per Census 2001)

\begin{tabular}{|l|l|l|l|l|l|l|}
\hline & Visual & Speech & Hearing & Movement & Mental & Total \\
\hline Uttarakhand & 85668 & $\begin{array}{l}16749 \\
(9 \%)\end{array}$ & $\begin{array}{l}15990 \\
(8 \%)\end{array}$ & $\begin{array}{l}56474 \\
(29 \%)\end{array}$ & $\begin{array}{l}19888 \\
(10 \%)\end{array}$ & 194769 \\
\hline India & 10634881 & 1640868 & 1261722 & 6105477 & 2263821 & 21906769 \\
\hline
\end{tabular}

Source: Census of India 2001 and Ministry of Health and Family Welfare, Central Bureau of Health Intelligence (2009), National Health Profile-2008, New Delhi, India p. 120.

Evidently, marginalisation has multiple bases in the social structure. The most dismal feature for the marginalised groups happens to be a social exclusion. This devious form of discrimination and exclusion is also marked with the 'persons with disabilities'. PWDs are amongst the most disempowered groups and have been subject to negligence; due to their marginal status they are denied the fundamental civil, political, social, economic and cultural rights that are the prerogative of all citizens in a democracy. They constantly faced the 
discrimination and were subjected to neglect, revulsion, rejection, prejudice and pity. They face economical, social, educational, health, legal barriers, which prevent them from leading a resourceful life and achieving their full potential. Historically in India as elsewhere in the world, there has been a deep-rooted cultural antipathy, persistent negative stereotypes and prejudice against persons with disabilities. Its socio-religious conceptualisation is that it is a divine retribution for past or present sins. Throughout the ages the disabled have been looked down upon with disdain, almost as if they were sub-human. They have been portrayed as medical discrepancy, helpless victims and a lifelong burden for family and society. (The World Bank Report, 2007) briefed that "persons with disability were excluded, segregated and deprived because of not only the physical and mental characteristics but also the social attitude that 'they will not be able to perform and contribute to social development'. It is pointed out that the low literacy, limited activities and widespread social stigma make persons with disabilities among the most excluded in India". Disabled people have been subjected to a multiplicity of oppressive social attitudes throughout history, which have included 'horror, fear, anxiety, hostility, distrust, pity, over-protection and patronizing behaviour' (Barton 1996; 235-248).

PWDs are routinely subjected to all forms of discrimination, denial and deprivation of rights with the result that they were often marginalised and excluded and made to live in a state of relative invisibility, disempowerment and disarticulation. European Disability Forum (EDF) policy paper graphically represents the cyclic nature of invisibility.

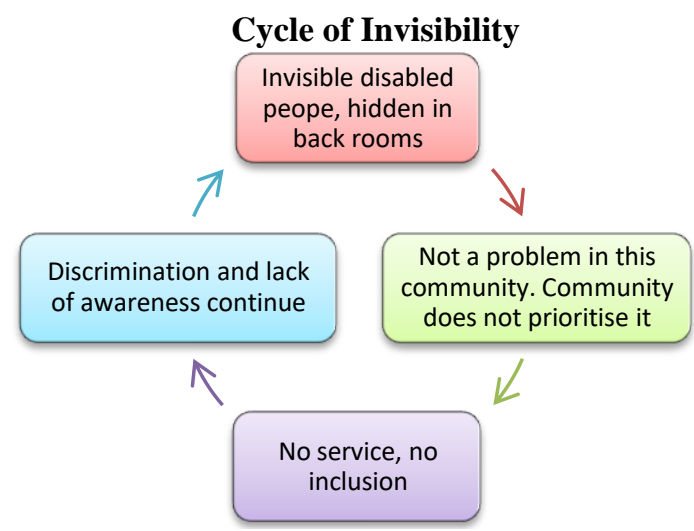

Source: EDF Policy Paper: "Development Cooperation and Disability" prepared by European Disability Forum (EDF) in 2003

\section{Disability Discourse in India}

According to estimates derived from Census of India 2001, $1.8 \%$ to $2.1 \%$ of total population of 1.2 billion suffers from some form of disability which in absolute number is approx 18.49 to 21.92 million persons. Using a wider definition of disability which includes conditions like diabetes and cardiovascular disease, the World Health Organisation (WHO) estimates that $6 \%$ to $10 \%$ of the population suffers from identifiable physical or mental disability that comes to over 70 million persons in India. Such phenomena as war, ethnic conflict, HIV/AIDS, industrial injuries, accidents are increasing the number of disabled persons (Addlakha 2010; 3).

The table below interpret the data on percentage of disabled persons for the Census 2001 and 2011.

Percentage of Disabled to Total Population in India, Census 2001-2011

\begin{tabular}{|l|l|l|l|l|l|l|}
\hline \multirow{2}{*}{ Residence } & $\mathbf{2 0 0 1}$ & $\mathbf{2 0 1 1}$ \\
\cline { 2 - 7 } & Persons & Male & Female & Persons & Male & Female \\
\hline Total & 2.13 & 2.37 & 1.87 & 2.21 & 2.41 & 2.01 \\
\hline Rural & 2.21 & 2.47 & 1.93 & 2.24 & 2.43 & 2.03 \\
\hline Urban & 1.93 & 2.12 & 1.71 & 2.17 & 2.34 & 1.98 \\
\hline
\end{tabular}

Source: C-Series, Table C-20, Census of India 2001-2011, Office of the Registrar General, New Delhi.

Percentage of disabled persons in India has increased both in rural and urban areas during the last decade and proportion of disabled population is higher in rural areas. There is a slight increase in disability among both the sexes over the decade; the proportion is higher among males with $55.9 \%$ and female $44.1 \%$. According to the study commissioned by Sightsavers India* in 2011, approx 75\% of PWDs live in rural areas, $51 \%$ of disabled population is illiterate and only $34 \%$ are employed. The Indian Census recognizes five** categories of disabilities namely visual, mental, locomotive, speech and auditory. The data of Census 2001 reveals that of the 5 types of disabilities, on which data has been collected, the visual and locomotive disabilities 
show the highest prevalence, hearing and speech disabilities combined constitute $13 \%$ of total disabilities (Addlakha 2010; 6). Graph below clears the picture.

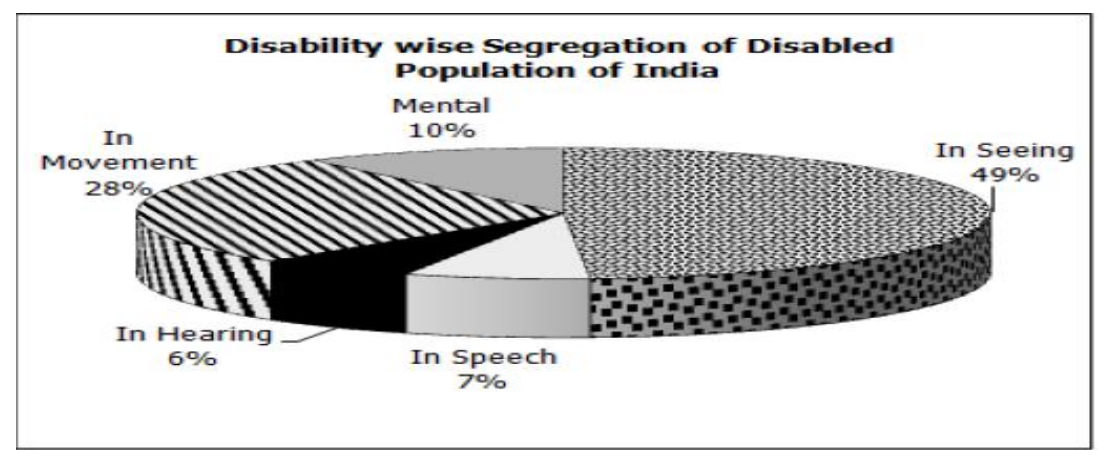

Various studies proved that the disability limits access to education and employment, and leads to economic and social exclusion. But disability is no longer an issue that can be conveniently brushed under the carpet. It is volatile, dynamic and very visible field. PWDs across the world had to fight a long battle to show the community that they are equally capable if they are just provided adequate support.

Instead of giving rights to disabled citizens and empowering them, a culture of charity and welfare has been systematically promoted in India since the colonial period. Medical rehabilitation including distribution of assistive aids and appliance and special schools, vocational training in low-end occupations and sheltered employment has been the pillars of state policy for the disabled. In historical texts, there are references to residential institutions and hospitals for the physically disabled that included the blind, crippled and deaf people and the infirm. These schools and residential institutions founded by $19^{\text {th }}$ century reformers aimed at providing education and vocational training to disabled people, mainly the visually and orthopedically impaired. There were also sporadic efforts to set up hospitals and charitable institutions but the problem of disabled were not addressed in a comprehensive manner (Mani 1988). However, an important step for providing accurate information towards guiding policy for the disabled was taken at the initiative of the colonial rulers, from the first Census in India 1872 to 1931, data about different categories of disabled people (physically and mentally disabled and leprosy affected) was collected (Ghosh 2012; 22).

While there was no clear policy during colonial rule and even after Independence, the general attitude towards the disabled has been one of charity and welfare. After Independence, the state accepted social welfare as a state responsibility, thus the welfare activities that had been the responsibility of voluntary or religious organisations now became state responsibility (Billimoria 1985).

The earlier emphasis on medical rehabilitation has now been replaced by an emphasis on social rehabilitation with right based approach. Disability has rightfully heralded a paradigm shift from 'charity' to 'right based approach'. There has been an increasing recognition of abilities of persons with disabilities and emphasis on mainstreaming them in the society based on their capabilities.

Disability is in the priority agenda of United Nations, World Bank and many other international and national bodies. Many international declarations and documents (including Human Rights Convention, Community Based Rehabilitation by UNESCO, ILO, WHO and UNICEF and UN Convention on Rights of Persons with Disabilities) have been projecting human rights approach towards the issues related to disability. The United Nation's International Year for Disabled Persons in 1981 played a key role in focussing international attention and funding on disability issues and supported the growing focus on the rights as well as the self identified needs of disabled people.

India has four dedicated Acts related to disability besides many constitutional provisions and remedial measures. In 2003 the Ministry of Social Justice \& Empowerment published the 'National Policy for Persons with Disabilities'. Further adopted a proactive approach in this area and is a signatory to many international declarations on disability. In October 2007, India has become one of the first few countries to ratify the 'UN Convention on Rights of Persons with Disabilities', a move that shows its willingness and commitment towards the issue.

The gamut of legislative measures has been taken for the effective implementation of safeguards provided under the Constitution for the protection, promote and propagate rights of the interests of persons with disabilities, which are as follows.

(1). The Mental Health Act, 1987 (2). The Persons with Disabilities (Equal Opportunities, Protection of Rights and Full Participation) Act, 1995: It is an effort to ensure equal opportunities for disable person and their full participation in nation building. 
(3). The National Trust for Welfare of Persons (with Autism, Cerebral Palsy, Mental Retardation and Multiple Disabilities) Act, 1999: It is a landmark legislation passed by Government. (4). Rehabilitation Council of India Act, 1986: It is to regulate and standardize training policies and programmes for rehabilitation of PWDs.

\section{PERSONS WITH DISABILITIES IN UTTARAKHAND STATE}

The Department of Social Welfare is the concerned authority for the welfare of People with Disability (PWD) in Uttarakhand. (Bisht et al 2010; 45-46) stated that the isolation of communities and adverse community attitudes towards people affected by disabilities, especially women, compound the problem in the state. More males $(2.65 \%)$ report with disabilities than females $(1.79 \%)$. Women with disabilities suffer a double discrimination, both on the grounds of gender and of impairment. Families with disabled heads are poorer, less educated and less healthy. Non working adults in the family increase the burden on children. Children with disabilities are often screened under Sarva Shiksha Abhiyaan but follow up is poor. Most PWDs will remain unemployed through their lives and therefore the family supporting them will be under greater economic strain. This has been a forgotten issue for the state and most development players and people living with disability are amongst the most vulnerable people in the state. Most disabilities are treatable if detected at an early age. Several studies made clear that the status of health, education, livelihood indicators are clearly depends on socio-economic condition and geographical location of individual, families and communities. There are many contributing factors like poor access to medical care after accident, low awareness on preventive and promotive health care practices including early immunization and poor social attitudes, as in Leprosy, AIDS.

Despite having a sound legal framework and a plethora of programmes, schemes, rules and regulations corresponding improvement in the circumstances of PWDs are not visible. The rate of illiteracy, unemployment, health and poverty among them is alarming. The table below shows the present scenario of number of PWDs and their type of disabilities as per Census 2011 in a state. Onwards Census of India 2011 information on eight types of disability has been collected.

Number of disabled persons and the type of disability (as per census 2011)

\begin{tabular}{|l|l|l|l|l|l|l|l|l|l|}
\hline & $\begin{array}{l}\text { Total } \\
\text { Disabled } \\
\text { Persons }\end{array}$ & Seeing & $\begin{array}{l}\text { Hearin } \\
\mathrm{g}\end{array}$ & Speech & $\begin{array}{l}\text { Moveme } \\
\mathrm{nt}\end{array}$ & $\begin{array}{l}\text { Mental } \\
\text { Retardat } \\
\text { ion }\end{array}$ & $\begin{array}{l}\text { Mental } \\
\text { Illness }\end{array}$ & $\begin{array}{l}\text { Any } \\
\text { Other }\end{array}$ & $\begin{array}{l}\text { Multip } \\
\text { le } \\
\text { Disabil } \\
\text { ity }\end{array}$ \\
\hline $\begin{array}{l}\text { Uttarakhan } \\
\text { d }\end{array}$ & 185272 & 29107 & 37681 & 12348 & 36996 & 11450 & 6443 & 30723 & 20524 \\
\hline India & 2681055 & 50324 & 50710 & 19985 & 5436604 & 1505624 & 72282 & 49270 & $\begin{array}{l}21164 \\
8\end{array}$ \\
\hline
\end{tabular}

Source: Census of India 2011, Department of Empowerment of Persons with Disabilities. Ministry of Social Justice and Empowerment, Government of India

The data in table below portray the district wise total and proportion of male and female PWDs in state during Census 2011.

District wise Population and Percentage of Persons with Disabilities in Uttarakhand (as per Census 2011)

\begin{tabular}{|l|l|l|l|l|l|l|}
\hline \multirow{2}{*}{ Districts } & \multicolumn{3}{|l|}{ Total Population of PWDs } & \multicolumn{2}{l|}{ Percentage of PWDs } \\
\cline { 2 - 7 } & Total & Male & Female & Total & Male & Female \\
\hline Uttarkashi & 6851 & 3770 & 3081 & 2.08 & 2.24 & 1.91 \\
\hline Chamoli & 8955 & 4677 & 4278 & 2.29 & 2.41 & 2.16 \\
\hline Tehri Garhwal & 13569 & 6961 & 6608 & 2.19 & 2.34 & 2.06 \\
\hline Dehradun & 30999 & 17755 & 13244 & 1.83 & 1.99 & 1.65 \\
\hline Pauri Garhwal & 12889 & 6892 & 5997 & 1.87 & 2.11 & 1.66 \\
\hline Rudraprayag & 5227 & 2595 & 2632 & 2.16 & 2.26 & 2.06 \\
\hline Pithoragarh & 9774 & 5310 & 4464 & 2.02 & 2.22 & 1.83 \\
\hline Almora & 13424 & 6922 & 6502 & 2.16 & 2.38 & 1.96 \\
\hline Nainital & 16093 & 9010 & 7083 & 1.69 & 1.83 & 1.54 \\
\hline Bageshwar & 4596 & 2500 & 2096 & 1.77 & 2.01 & 1.55 \\
\hline Champawat & 3541 & 2047 & 1494 & 1.36 & 1.56 & 1.16 \\
\hline Haridwar & 31489 & 18463 & 13026 & 1.67 & 1.84 & 1.47 \\
\hline U.S.Nagar & 27865 & 15885 & 11980 & 1.69 & 1.85 & 1.52 \\
\hline
\end{tabular}




\begin{tabular}{|l|l|l|l|l|l|l|}
\hline Uttarakhand & 185272 & 102787 & 82485 & 1.84 & 2.00 & 1.67 \\
\hline
\end{tabular}

Source: Statistical Diary (2014-15), Directorate of Economic and Statistical, Government of Uttarakhand, Dehradun, p. 29.

There is no specific study has been done yet in the state to understand the various aspects of among people with disability in relation to their employment status and income generation interventions. Several studies proved that disabled persons are the most vulnerable and disadvantaged group in across the community. They faces significant challenges in maintaining their livelihood activities as they are not able to getting access to proper education and get skilled jobs thus driving them further into poverty.

To address the health issues of Uttarakhand, Government formulated a comprehensive, integrated, state-specific health and population policy. Many of these policy targets are related to the disability prevention.

\section{Health Objectives:}

- Eradicate polio by 2007.

- Reduce the level of leprosy to below 1 per 10,000 population by December 2007 (Uttarakhand has achieved $\mathrm{P} / \mathrm{R}-0.72 / 10000)$

- Reduce mortality from tuberculosis, malaria, and other vector and water-borne diseases by 50 percent by 2010.

- Reduce prevalence of blindness from around 1 to 0.3 percent by 2010 .

- Reduce Iodine Deficiency Disorder (IDD) by 50 percent of the present level by 2010.

- Reduce RTIs to below 10 percent among men and women by 2007.

- Increase awareness on HIV/AIDS.

The government of Uttarakhand has not enacted any legislation specifically for PWDs. The state has implemented some social protection initiatives and schemes.

\section{Education for all:}

The State Government is progressing towards the provision of 'education for all'. Since the implementation of Persons with Disabilities Act 1995, India has overcome a major 'legislative hurdle' to promote inclusive education (Sharma and Deppeler 2005). With SSA (Sarva Siksha Abhiyaan), RMSA (Rashtriya Madhyamik Shiksha Abhiyaan) and Right to Education Act it becomes imperative that every child without any discrimination be enrolled in the schools. This automatically calls for a compulsory enrolment of all the children with disabilities as well. For achieving target of $100 \%$ enrolment one of the focus of the government is on including Children with Special Needs (CWSN) in regular schools. The social and geographical demography of the state has implications for the education of CWSN. For the successful implementation of any programme for inclusion of CWSN, these issues need to be critically examined and resolved. The total number of CWSN identified by SSA in the state in 2011-12 was 21392 (categories, VI, HI, SI, OI, LD, MR, MD and CP). Out of which 17951 are in schools and 3441 are covered by Home based education. Large number of barriers prevents children with special needs from getting access to education in the state. The number of enrolment has increased in the year 2012-13 in which out of 21,898 CWSN identified 18,040 have been enrolled in schools and 3028 CWSN are proposed to be covered through home based education (Rajeshwari and Saxena 2014; 81). This indicates the positive achievement of the government towards the education of children with special needs. The State government awards scholarships/stipend to the disabled students $(\mathrm{OH} / \mathrm{VH} / \mathrm{HH})$. Scholarship are provided from class first to post graduate level education (scholarship amount is subject to revise).

\section{SOCIAL PROTECTION:}

The State Government provides a maintenance grant to destitute PWDs at the rate of Rs. 800 per month. Under the Social Security Pension Scheme, known as 'Viklang Bharan Poshan Anudaan' the State Government sanctioned disability pension of Rs. 400 per month for PWDs whose age should be above 18 years, who either belong to BPL category or persons whose monthly income does not exceed Rs. 4000 per month and person should have at least $40 \%$ of disability. The State provides incentive for marrying a disabled person. The disabled persons get assistance for self-employment. Rs. 11,000 is given as a grant when the bridegroom is disabled and a grant of Rs. 14,000 where either the bride or both are disabled, but from November 2014 grant has been increased to Rs 25000. Persons with Disabilities are eligible to travel free of cost in buses of the State Road Transport Corporation.

Under the welfare scheme of Assistance for purchase of Aids and Appliances the State provides the grants to handicapped persons in order to improve their mobility by acquire artificial organs, aids and appliances. Free aids and appliances within 500 to 3500 limits are given to those handicapped persons whose 
parent's or self monthly income not exceeding Rs.4000. The State Government has also introduced a Shop Construction Rehabilitation Scheme for Economic Assistance for Self Employment wherein support up to 20,000 for starting one's own shop or small business for those who own a piece of land. The government provides Rs. 15,000 as loan at an interest of 4\% (Sightsavers 2011; 117, Social Welfare Department of Govt. of Uttarakhand). The State Government conducts camps and seminars for the awareness and convenience of PWDs. Various training centres, short term courses and workshop are operated for the physically disabled persons for their skill development and employment generations The State Policy on PWDs focuses on the prevention of disabilities and timely assistance to persons with disabilities to lead as normal a life as possible within a family and the community. The policy envisages a joint responsibility for the government, NGOs, philanthropists and the community as a whole.

\section{CONCLUSION AND RECOMMENDATIONS:}

The path to enhance the status of persons with disabilities lies in the removal of social, economic and psychological barriers that devalue and discriminate them, while guaranteeing unfettered access to quality health care, education, employment and recreation. The main question arises here is how can disabled be assured of economic and social independence and the answer lies in only by expanding educational and rehabilitative services and empowering them by providing vocational training, skill development mainly in the rural areas of the country. The education, even professional qualification may not guarantee the disabled person a suitable economic and social status until there is no positive change in a narrow mindset of people against them. Inclusion into income generating activities and skill development are two important ways of supporting extremely poor disabled people and reducing their vulnerabilities. The involvement with income generating activities or the productive use of an asset provided disabled people the opportunity to improve their incomes and social dignity and allowed them to strengthen their ability to cope with crises or shocks in a sustainable way. Community Based Rehabilitation (CBR) can also improve skills and attitudes of disabled persons, support on the job training and provide guidance to employers. Strengthening local inclusive self-help group at community level can build motivation and encouragement of people with disability to maintain their participation in regular activities. To build an inclusive society an honest effort should be made with more inclusive approach in which equal opportunities are provided for the growth and development of Persons with Disabilities so that they can lead productive, safe and dignified lives. We need to advocate the sustainable development measures that can bring about equity in society and not disparity.

\section{REFERENCES AND NOTES:}

[1] Note: * Sightsavers along with Blind People's Association (Ahmedabad) has taken a considerable effort to compile the information on the various policies and schemes of the central and state government in India for People with Disabilities.

[2] ** In Census 2011 information on eight types of disability has been collected i.e. in seeing, in hearing, in speech, in movement, mental retardation, mental illness, any other, multiple disability.

[3] *** State Grants are subject to revise.

[4] The World Bank Report (2007), 'People with Disability in India: From Commitments to Outcomes', Human Development Unit, South Asian Region, The World Bank, New Delhi.

[5] Barton, Len (1996), 'The Struggle for Citizenship: The Case of Disabled People', Disability, Handicap and Society, 8(3), pp 235-248.

[6] Addlakha, Renu (2010), 'From Invalidation and Segregation to Recognition and Integration: Contemporary State Responses to Disability in India', Occasional Paper No. 55, Centre for Women's Development Studies, September, New Delhi.

[7] www.sightsaversindia.in

[8] Mani, D. Rama (1988), 'The Physically Handicapped in India: Policy and Programme', Ashish Publishing House, New Delhi.

[9] Ghosh, Nandini (2012), 'Disabled Definitions, Impaired Policies: Reflections on Limits of Dominant Concepts of Disability', Occasional Paper No. 34, Institute of Development Studies, Kolkata, May, p 22.

[10] Billimoria, R.B. (1985), 'Educating the Mentally Retarded: A Study of Special Schools in Bombay, Ph.D Thesis, Tata Institute of Social Sciences, Mumbai.

[11] Bisht, Khila, Aditi P. Kaur, Satyendra Srivastava and Cyril R. Raphael (2010), 'State Strategy Paper Uttarakhand: Identifying Key Issues', $31^{\text {st }}$ March, Oxfam India, p. 45-46.

[12] Sharma, U. and Deppeler, J. (2005), 'Integrated Education in India: Challenges and Prospects', Disabilities Studies Quarterly, 25 (1).

[13] Rajeshwari, S. and V. Saxena (2014), 'Travelling through the Hills: Exploring the Educational Journey of Children with Special Needs', Educationia Confab, Vol. 3, No.1, January, pp 79-85. 